\title{
Influence of varied crop residues and green biomass composts to rabi sorghum growing soils on uptake of major nutrients, microbial biomass and soil fertility status
}

\author{
Ashwini Ambadi ${ }^{1}$, D. Krishnamurty ${ }^{2 *}$, Sathyanaran Rao ${ }^{3}$, B. K. Desai ${ }^{1}$, M.V. Ravi ${ }^{4}$ and \\ S. Shubha ${ }^{5}$ \\ ${ }^{1}$ Department of Agronomy, University of Agricultural Sciences, Raichur-584104 (Karnataka), INDIA \\ ${ }^{2}$ Directorate of Research, University of Agricultural Sciences, Raichur-584104 (Karnataka), INDIA \\ ${ }^{3}$ Research Institute on Organic Farming, University of Agricultural Sciences, Raichur-584104 (Karnataka), INDIA \\ ${ }^{4}$ Department of Soil Science, University of Agricultural Sciences, Raichur-584104 (Karnataka), INDIA \\ ${ }^{5}$ Department of Agricultural Microbiology, University of Agricultural Sciences, Raichur-584104(Karnataka), \\ INDIA \\ *Corresponding author. E-mail: murthyagron@gmail.com
}

Received: December 10, 2016; Revised received: September 3, 2017; Accepted: January 25, 2018

\begin{abstract}
A field experiment was conducted on vertisols ( $\mathrm{pH}$ of 7.56 with organic carbon content of $0.55 \%)$ at $\mathrm{Re}$ search Institute on Organic Farming, University of Agricultural Sciences, Raichur coming under northern Karnataka during rabi season of 2015-16 to study the Influence of varied crop residues and green biomass composts to rabi sorghum growing soils on uptake of major nutrients, organic carbon and soil fertility status. In general application of Cotton stalks, Redgram stalks, Glyricidia, combination of cotton and redgram stalks composts, FYM and combination of organic and inorganic fertilizers helped to buildup soil nutrients with respect to organic carbon, available nitrogen and phosphorus. Significantly higher nitrogen $\left(227.3 \mathrm{~kg} \mathrm{ha}^{-1}\right)$, phosphorous $\left(75.7 \mathrm{~kg} \mathrm{ha}^{-1}\right)$ and potassium (141.7 $\left.\mathrm{kg} \mathrm{ha}^{-1}\right)$ uptake by rabi sorghum was recorded with combined application of recommended FYM $\left(3 \mathrm{t} \mathrm{ha}^{-1}\right)$ and NP fertilizers $\left(50: 25 \mathrm{~kg} \mathrm{~N}, \mathrm{P}_{2} \mathrm{O}_{5} \mathrm{ha}^{-1}\right)\left(\mathrm{T}_{14}\right)$ followed by Cotton stalks +Redgram stalks + Glyricidia sp. with C:N ratio of $30: 1$ compost @ $50 \mathrm{~kg} \mathrm{~N}$ equivalent $\left(\mathrm{T}_{12}: 222.0,74.0\right.$ and $\left.132.3 \mathrm{~kg} \mathrm{ha}^{-1}\right)$. The least uptake was recorded with absolute control $\left(T_{15}: 127.0,42.0\right.$ and $\left.71.7 \mathrm{~kg} \mathrm{ha}^{-1}\right)$. Similar trend was observed with organic carbon, available nitrogen and phosphorus. Combined application of recommended FYM $\left(3 \mathrm{t} \mathrm{ha}^{-1}\right)$ and NP fertilizers $\left(50: 25 \mathrm{~kg} \mathrm{~N} \mathrm{P}_{2} \mathrm{O}_{5} \mathrm{ha}^{-1}\right)$ followed by Cotton stalks +Redgram stalks + Glyricidia sp. with C:N ratio of 30:1 compost @ $50 \mathrm{~kg} \mathrm{~N}$ equivalent at the time of sowing recorded higher major nutrients uptake, microbial biomass and soil fertility status.
\end{abstract}

Keywords: Availability, Composts, Nutrients, Soil Fertility status, Sorghum, Uptake

\section{INTRODUCTION}

Productive agriculture is dependent upon sound soil nutrient management practices. Seventeen elements are known to be essential for plants. Over years of intensive cultivation and imbalanced fertilizer use, Indian soils have become deficient in several of these nutrients and are also impoverished in organic matter. Yields of various crops have reached a plateau or are on the decline. This is of serious consequence given increasing population and diminishing per capita land availability. Several methods of nutrient management have been practiced on farms, however, the best option for the farmer is an integration of organic and inorganic approaches to nutrient management. This far a lot of emphasis has been placed on the conservation and management of $\mathrm{N}$-one of the earliest reported scarce plant nutrient. However, current studies across India have shown a gradual and alarming depletion of potassium and increase in P fixation leading to sustainability concerns for these two nutrients. Among other nutrients $\mathrm{S}, \mathrm{Zn}$ and $\mathrm{B}$ are also reaching deficient status in Indian soils (Ramakrishna Parama and Atheefa Munawery, 2012).

Sorghum is cultivated during both rainy (kharif) and post-rainy (rabi) season, mainly as a rainfed crop in India. Sorghum cultivation is gaining popularity due to its nature of extreme drought tolerance and is very nutritious just like corn and can be used as green fodder, dry fodder, hay or silage. Currently, the energy crises associated with hike in prices of nitrogen, phosphorus and potassium fertilizers has made the use of chemical fertilizers not only costly but also scarce at peak times of demand. It is imperative to make use of organic sources to maintain healthy crop growth and to obtain sustainable yield and quality. Cotton and red- 
gram residues viz. crop by-products have low fodder value or waste of threshing yard, which have high carbon to nitrogen ratio (22 to $99: 1)$ and less suitable for direct use. Further the quality of the conventional organic manure is poor. In addition to this some of the farmers are using these stalks as source of raw materials for production of composts without knowing exact proportion of mixing green biomass and its impact on crops and soil. Therefore, to develop a suitable technique for production of enriched organic manure with crop residues and green biomass, as a nutrient source and its effect on soil fertility status of soil, present investigation is necessary.

\section{MATERIALS AND METHODS}

A field experiment was conducted during rabi season of 2015-16 at Research Institute on Organic Farming, University of Agricultural Sciences, Raichur situated in North Eastern Dry Zone of Karnataka at $16^{\circ} 15^{\prime} \mathrm{N}$ latitude and $77^{\circ} 20^{\prime} \mathrm{E}$ longitude with an altitude of 389 meters above the mean sea level. The experiment consisted of fifteen treatments, of which twelve treatments were based on recommended nitrogen supply through cotton stalks, redgram stalks, Glyricidia, combination of cotton and redgram stalks composts, FYM and combination of organic and inorganic fertilizers, RDF (50:25 N: $\mathrm{P}_{2} \mathrm{O}_{5} \mathrm{~kg} \mathrm{ha}^{-1}$ ) and one absolute control (Table 1). The experiment was laid in RCBD (Randomized Complete Block Design) with three replications.

The soil was deep black clayey in texture with $\mathrm{pH}$ and organic carbon content ( 7.56 and $0.55 \%$, respectively). The soils were low in available nitrogen, high in available phosphorus and available potassium (140.28, 55.34 and $413.21 \mathrm{~kg} \mathrm{ha}^{-1}$, respectively). It was analyzed from the collected composite soil sample of 0 to $15 \mathrm{~cm}$ depth in experimental plot before sowing. Soil sample was air dried, powdered, passed through $2 \mathrm{~mm}$ sieve and analysed for physic-chemical and biological properties of soil. The $\mathrm{pH}, \mathrm{EC}, \mathrm{OC}$, available soil nitrogen was estimated by alkaline potassium permanga- nate method as outlined by Subbaiah and Asija (1956). Available phosphorus was determined by Olsen's method as outlined by Jackson (1967) using spectrophotometer. Available potassium was extracted with neutral normal ammonium acetate and the content was estimated by flame photometer (Jackson, 1967). Recommended packages of practices were adopted for crop production. All the data were analyzed statistically as outlined by Panse and Sukhatme (1967).

\section{RESULTS AND DISCUSSION}

Uptake of nutrients: Significantly higher nitrogen, phosphorous and potassium uptake by rabi sorghum was recorded with application of recommended FYM (3 $\mathrm{t} \mathrm{ha}^{-1}$ ) and NP fertilizers $\left(50: 25 \mathrm{~kg} \mathrm{~N}, \mathrm{P}_{2} \mathrm{O}_{5} \mathrm{ha}^{-1}\right)$ application $\left(\mathrm{T}_{14}: 227.3,75.7\right.$ and $141.7 \mathrm{~kg} \mathrm{ha}^{-1}$, respectively) followed by Cotton stalks +Redgram stalks + Glyricidiasp. with C:N ratio of 30:1 compost @ $50 \mathrm{~kg}$ $\mathrm{N}$ equivalent $\left(\mathrm{T}_{12}: 222.0,74.0\right.$ and $\left.132.3 \mathrm{~kg} \mathrm{ha}^{-1}\right)$. The least uptake was recorded with absolute control $\left(\mathrm{T}_{15}\right.$ : 127.0, 42.0 and $71.7 \mathrm{~kg} \mathrm{ha}^{-1}$ ) (Table 2). This could be attributed to application of FYM @3 t ha ${ }^{-1}$ with in organic fertilizers might have improved the nutritional environment in root zone as well as in the plant system leading to increased in uptake and translocation of nutrients especially nitrogen and phosphorous in the reproductive structure leading to higher content and uptake. Since uptake of nutrients is the function of grain and stover yield and their nutrient content, the significant improvement in content of these nutrients coupled with increased grain and stover yield and total uptake of nitrogen, phosphorous and potassium substantially was recorded. Increase in uptake of $\mathrm{N}$ was also due to increase in dry matter production and content. These results are in close conformity of Lalitha et al. (2015) who reported that among the organic manures, the residual left over with respect to the major nutrients was commensurate with respective nutrient content of different organic manures and depletion pattern of nutrients due to differential uptake by onion and other crops. The higher $\mathrm{P}$ was due to the influence

Table 1. Compost and treatment details.

\begin{tabular}{|c|c|c|}
\hline Compost & Treatment No & Treatment details \\
\hline $\mathrm{C}_{1}$ & $\mathrm{~T}_{1}$ & Cotton stalks with the initial C:N of $96: 1$ \\
\hline $\mathrm{C}_{2}$ & $\mathrm{~T}_{2}$ & Redgram stalks with the initial $\mathrm{C}: \mathrm{N}$ of $80: 1$ \\
\hline $\mathrm{C}_{3}$ & $\mathrm{~T}_{3}$ & Glyricidia $s p$. with the initial C:N of $22: 1$ \\
\hline $\mathrm{C}_{4}$ & $\mathrm{~T}_{4}$ & Cotton stalks + Glyricidia $s p$. with initial C:N of $50: 1$ \\
\hline $\mathrm{C}_{5}$ & $\mathrm{~T}_{5}$ & Cotton stalks + Glyricidia $s p$. with initial C:N of $40: 1$ \\
\hline $\mathrm{C}_{6}$ & $\mathrm{~T}_{6}$ & Cotton stalks + Glyricidia $s p$. with initial C:N of $30: 1$ \\
\hline $\mathrm{C}_{7}$ & $\mathrm{~T}_{7}$ & Redgram stalks + Glyricidia $s p$. with initial $\mathrm{C}: \mathrm{N}$ of $50: 1$ \\
\hline $\mathrm{C}_{8}$ & $\mathrm{~T}_{8}$ & Redgram stalks + Glyricidia $s p$. with initial C:N of $40: 1$ \\
\hline $\mathrm{C}_{9}$ & $\mathrm{~T}_{9}$ & Redgram stalks + Glyricidia $s p$. with initial C:N of $30: 1$ \\
\hline $\mathrm{C}_{10}$ & $\mathrm{~T}_{10}$ & Cotton stalks + Redgram stalks + Glyricidia $s p$. with initial C:N of 50:1 \\
\hline $\mathrm{C}_{11}$ : & $\mathrm{T}_{11}$ : & Cotton stalks + Redgram stalks + Glyricidia $s p$. with initial C:N of 40:1 \\
\hline $\mathrm{C}_{12}$ & $\mathrm{~T}_{12}$ & Cotton stalks + Redgram stalks + Glyricidia sp. with initial C:N of $30: 1$ \\
\hline- & $\mathrm{T}_{13}$ & Recommended NP fertilizers $\left(50: 25 \mathrm{~N}, \mathrm{P}_{2} \mathrm{O}_{5} \mathrm{~kg} \mathrm{ha}^{-1}\right)$ \\
\hline- & $\mathrm{T}_{14}$ & Recommended FYM $\left(3 \mathrm{tha}^{-1}\right)$ and NP fertilizers $\left(50: 25 \mathrm{~N}, \mathrm{P}_{2} \mathrm{O}_{5} \mathrm{~kg} \mathrm{ha}^{-1}\right)$ \\
\hline- & $\mathrm{T}_{15}$ & Absolute control \\
\hline
\end{tabular}


Ashwini Ambadi et al. / J. Appl. \& Nat. Sci. 10(1): 185 - 189 (2018)

Table 2. Uptake of nitrogen, phosphorus and potassium by rabi sorghum as influenced by different composts.

\begin{tabular}{|c|c|c|c|}
\hline Treatments & Nitrogen $\left(\mathrm{kg} \mathrm{ha}^{-1}\right)$ & Phosphorous (kg ha ${ }^{-1}$ ) & Potassium $\left(\mathrm{kg} \mathrm{ha}^{-1}\right)$ \\
\hline $\mathrm{T}_{1}: \mathrm{C}_{1}$-Compost & 176.3 & 49.0 & 100.6 \\
\hline $\mathrm{T}_{2}: \mathrm{C}_{2}$-Compost & 186.7 & 51.7 & 104.7 \\
\hline $\mathrm{T}_{3}: \mathrm{C}_{3}$-Compost & 193.0 & 61.0 & 114.0 \\
\hline $\mathrm{T}_{4}: \mathrm{C}_{4}$-Compost & 176.3 & 56.0 & 106.2 \\
\hline $\mathrm{T}_{5}: \mathrm{C}_{5}$-Compost & 186.0 & 58.0 & 107.4 \\
\hline $\mathrm{T}_{6}: \mathrm{C}_{6}$-Compost & 194.7 & 59.0 & 107.6 \\
\hline $\mathrm{T}_{7}: \mathrm{C}_{7}$-Compost & 185.3 & 55.0 & 113.0 \\
\hline $\mathrm{T}_{8}: \mathrm{C}_{8}$-Compost & 193.7 & 60.0 & 116.9 \\
\hline $\mathrm{T}_{9}: \mathrm{C}_{9}$-Compost & 201.3 & 64.0 & 117.3 \\
\hline $\mathrm{T}_{10}: \mathrm{C}_{10}$-Compost & 186.3 & 65.0 & 122.3 \\
\hline $\mathrm{T}_{11}: \mathrm{C}_{11}$-Compost & 205.0 & 66.7 & 126.9 \\
\hline $\mathrm{T}_{12}: \mathrm{C}_{12}$-Compost & 222.0 & 74.0 & 132.3 \\
\hline $\begin{array}{lll}\mathrm{T}_{13}: \text { Recommended } & \mathrm{NP} & \text { fertilizers } \\
\left(50: 25 \mathrm{~kg} \mathrm{~N} \mathrm{P}_{2} \mathrm{O}_{5} \mathrm{ha}^{-1}\right) & \end{array}$ & 221.0 & 72.7 & 119.1 \\
\hline $\begin{array}{l}\mathrm{T}_{14} \text { : Recommended FYM }\left(3 \mathrm{t} \mathrm{ha}^{-1}\right) \text { and NP fertilizers } \\
\left(50: 25 \mathrm{~kg} \mathrm{~N}, \mathrm{P}_{2} \mathrm{O}_{5} \mathrm{ha}^{-1}\right)\end{array}$ & 227.3 & 75.7 & 141.7 \\
\hline $\mathrm{T}_{15}:$ Absolute control & 127.0 & 42.0 & 71.7 \\
\hline $\mathbf{S . E m} \pm$ & 1.84 & 0.75 & 3.5 \\
\hline C.D. $(P=0.05)$ & 5.46 & 2.17 & 10.1 \\
\hline
\end{tabular}

$\mathrm{T}_{1}$ to $\mathrm{T}_{12}$ :Compost was applied @ $50 \mathrm{~kg} \mathrm{~N} \mathrm{ha}{ }^{-1}$

Table 3. Population of different groups of microorganisms in soil after harvest of rabi sorghum as influenced by different composts.

\begin{tabular}{|c|c|c|c|}
\hline Treatments & $\begin{array}{l}\text { Bacteria } \\
\left(\text { NoX } 10^{7} \mathrm{CFUg}^{-1} \text { of soil) }\right.\end{array}$ & $\begin{array}{l}\text { Fungi } \\
\text { (No X } 10^{4} \mathrm{CFUg}^{-1} \text { of soil) }\end{array}$ & $\begin{array}{l}\text { Actinomycetes (No } X \\
10^{3} \mathrm{CFUg}^{-1} \text { of soil) }\end{array}$ \\
\hline $\mathrm{T}_{1}: \mathrm{C}_{1}$-Compost & 33.1 & 26.2 & 18.1 \\
\hline $\mathrm{T}_{2}: \mathrm{C}_{2}$-Compost & 35.9 & 28.0 & 18.2 \\
\hline $\mathrm{T}_{3}: \mathrm{C}_{3}$-Compost & 40.9 & 31.6 & 20.1 \\
\hline $\mathrm{T}_{4}: \mathrm{C}_{4}$-Compost & 35.8 & 26.2 & 18.2 \\
\hline $\mathrm{T}_{5}: \mathrm{C}_{5}$-Compost & 37.6 & 26.8 & 18.9 \\
\hline $\mathrm{T}_{6}: \mathrm{C}_{6}$-Compost & 40.3 & 27.6 & 20.5 \\
\hline $\mathrm{T}_{7}: \mathrm{C}_{7}$-Compost & 38.1 & 28.6 & 18.7 \\
\hline $\mathrm{T}_{8}: \mathrm{C}_{8}$-Compost & 40.0 & 30.4 & 19.7 \\
\hline $\mathrm{T}_{9}: \mathrm{C}_{9}$-Compost & 41.8 & 37.1 & 22.2 \\
\hline $\mathrm{T}_{10}: \mathrm{C}_{10}$-Compost & 42.6 & 35.1 & 21.5 \\
\hline $\mathrm{T}_{11}: \mathrm{C}_{11}$-Compost & 44.7 & 36.0 & 22.8 \\
\hline $\mathrm{T}_{12}: \mathrm{C}_{12}$-Compost & 47.3 & 37.4 & 24.6 \\
\hline $\begin{array}{l}\mathrm{T}_{13}: \text { Recommended } \mathrm{NP} \text { fertilizers } \\
\left(50: 25 \mathrm{~kg} \mathrm{~N} \mathrm{P}_{2} \mathrm{O}_{5} \mathrm{ha}^{-1}\right)\end{array}$ & 40.5 & 33.2 & 20.7 \\
\hline $\begin{array}{l}\mathrm{T}_{14} \text { : Recommended FYM }\left(3 \mathrm{tha}^{-1}\right) \text { and } \\
\text { NP fertilizers }\left(50: 25 \mathrm{~kg} \mathrm{~N}, \mathrm{P}_{2} \mathrm{O}_{5} \mathrm{ha}^{-1}\right)\end{array}$ & 45.4 & 39.7 & 23.9 \\
\hline $\mathrm{T}_{15}:$ Absolute control & 22.9 & 20.0 & 11.8 \\
\hline S.Em \pm & 1.01 & 0.86 & 0.61 \\
\hline C.D. $(P=0.05)$ & 2.91 & 2.59 & 1.83 \\
\hline
\end{tabular}

$\mathrm{T}_{1}$ to $\mathrm{T}_{12}$ :Compost was applied @ $50 \mathrm{~kg} \mathrm{~N}$ ha $^{-1}$

of organics and organic acids produced during decomposition of organic materials in soils resulted in mineralizing the insoluble phosphate into more soluble phosphates (Bellaki et al., 1997).

Soil microbial biomass: The soil beneficial microorganisms such as soil bacteria, fungi and actinomycetes population differed significantly due to different composts (Table 3) The application of recommended fertilizers $\left(50: 25 \mathrm{~N}: \mathrm{P}_{2} \mathrm{O}_{5} \mathrm{~kg} \mathrm{ha}^{-1}\right)+$ FYM @ $3 \mathrm{t} \mathrm{ha}^{-1}$ plus recorded significantly highest soil bacteria (45.4 cfu $\times 10^{6} \mathrm{~g}^{-1}$ of soil), fungi $\left(39.7 \mathrm{cfu} \times 10^{4} \mathrm{~g}^{-1}\right.$ soil $)$ and actinomycetes $\left(23.9 \mathrm{cfu} \times 10^{3} \mathrm{~g}^{-1}\right.$ soil $)$ populations at harvest. This could be due to cumulative effect of FYM in increasing organic carbon content of soil which acted as carbon and energy source for microbes and their quick build up in the soil (Rita and Varde, 1998). Lowest soil bacteria $\left(22.9 \mathrm{cfu} \times 10^{6} \mathrm{~g}^{-1}\right.$ of soil), fungi (20.0 cfu $\times 10^{4} \mathrm{~g}^{-1}$ soil) and actinomycetes $\left(11.8 \mathrm{cfu} \times 10^{3} \mathrm{~g}^{-1}\right.$ soil) populations were noticed in control as compared to other treatments. These results are in line with the findings of Deshpande et al. (2010) and Sharada (2013) who reported higher population of soil microflora viz., bacteria, fungi, actinomycetes, free living nitrogen fixers and PSB at different growth stages of both greengram and rabi sorghum with combined application of organic manures along with panchagavya. 
Table 4. Effect of different composts on $\mathrm{pH}$, electrical conductivity $\left(\mathrm{dS} \mathrm{m}^{-1}\right)$, organic carbon $\left(\mathrm{g} \mathrm{kg}^{-1}\right)$ and available NPK $(\mathrm{kg}$ ha $\left.{ }^{1}\right)$ status in soil after harvest of rabi sorghum.

\begin{tabular}{|c|c|c|c|c|c|c|}
\hline Treatments & pH & EC & OC & $\begin{array}{l}\text { Avail. } \\
\mathbf{N}\end{array}$ & $\begin{array}{l}\text { Avail. } \\
\mathrm{P}_{2} \mathrm{O}_{5}\end{array}$ & $\begin{array}{l}\text { Avail. } \\
\mathrm{K}_{2} \mathrm{O}\end{array}$ \\
\hline $\mathrm{T}_{1}: \mathrm{C}_{1}$-Compost & 6.9 & 0.35 & 6.1 & 184.7 & 61.3 & 468.7 \\
\hline $\mathrm{T}_{2}: \mathrm{C}_{2}$-Compost & 7.0 & 0.34 & 6.1 & 194.0 & 66.0 & 487.0 \\
\hline $\mathrm{T}_{3}: \mathrm{C}_{3}$-Compost & 7.1 & 0.35 & 6.2 & 200.7 & 74.7 & 493.0 \\
\hline $\mathrm{T}_{4}: \mathrm{C}_{4}$-Compost & 7.2 & 0.35 & 6.1 & 186.0 & 65.3 & 473.0 \\
\hline $\mathrm{T}_{5}: \mathrm{C}_{5}$-Compost & 7.3 & 0.33 & 6.2 & 188.0 & 66.7 & 479.0 \\
\hline $\mathrm{T}_{6}: \mathrm{C}_{6}$-Compost & 7.2 & 0.36 & 6.1 & 195.0 & 67.7 & 485.0 \\
\hline $\mathrm{T}_{7}: \mathrm{C}_{7}$-Compost & 7.3 & 0.35 & 6.2 & 194.7 & 71.7 & 492.3 \\
\hline $\mathrm{T}_{8}: \mathrm{C}_{8}$-Compost & 7.3 & 0.36 & 6.1 & 204.0 & 76.0 & 497.0 \\
\hline $\mathrm{T}_{9}: \mathrm{C}_{9}$-Compost & 7.1 & 0.35 & 6.1 & 212.7 & 77.0 & 496.0 \\
\hline $\mathrm{T}_{10}: \mathrm{C}_{10}$-Compost & 7.3 & 0.35 & 6.2 & 204.3 & 71.7 & 501.3 \\
\hline $\mathrm{T}_{11}: \mathrm{C}_{11}$-Compost & 7.3 & 0.36 & 6.1 & 217.0 & 75.7 & 511.3 \\
\hline $\mathrm{T}_{12}: \mathrm{C}_{12}$-Compost & 7.2 & 0.36 & 6.3 & 224.7 & 81.3 & 518.7 \\
\hline $\mathrm{T}_{13}$ :Recommended NP fertilizers $\left(50: 25 \mathrm{~kg} \mathrm{~N}, \mathrm{P}_{2} \mathrm{O}_{5}\right.$ ha $\left.^{-1}\right)$ & 7.4 & 0.40 & 5.8 & 185.0 & 65.0 & 455.7 \\
\hline $\begin{array}{l}\mathrm{T}_{14}: \text { Recommended FYM }\left(3 \mathrm{tha}^{-1}\right) \text { and NP fertilizers } \\
\left(50: 25 \mathrm{~kg} \mathrm{~N}, \mathrm{P}_{2} \mathrm{O}_{5} \mathrm{ha}^{-1}\right)\end{array}$ & 7.2 & 0.37 & 6.2 & 234.0 & 87.0 & 519.7 \\
\hline $\mathrm{T}_{15}:$ Absolute control & 6.8 & 0.32 & 4.8 & 132.7 & 46.3 & 447.5 \\
\hline S.Em \pm & 0.11 & 0.02 & 0.06 & 3.17 & 1.93 & 2.92 \\
\hline C.D. $(P=0.05)$ & NS & NS & 0.17 & 9.50 & 5.80 & 8.75 \\
\hline
\end{tabular}

$\mathrm{T}_{1}$ to $\mathrm{T}_{12}$ :Compost was applied @ $50 \mathrm{~kg} \mathrm{~N} \mathrm{ha}^{-1}$

Soil fertility status at harvest: Organic carbon content of the soil improved with the application of different composts and FYM in combination with chemical fertilizers (Table 3). The higher organic carbon content was mainly due to addition of carbon rich organic manures. Hundekar et al. (1997) reported that incorporation of organic residues like cotton, redgram and sorghum stubbles at rate of $5 \mathrm{tha}^{-1}$ in combination with inorganic fertilizers significantly increased organic carbon and available N, P, K content of soil.

Available nitrogen content in soil increased with application of recommended FYM $\left(3 \mathrm{tha}^{-1}\right)$ and NP fertilizers $\left(50: 25 \mathrm{~kg} \mathrm{~N}, \mathrm{P}_{2} \mathrm{O}_{5} \mathrm{ha}^{-1}\right)$ application $\left(234.0 \mathrm{~kg} \mathrm{ha}^{-1}\right)$ followed by Cotton stalks +Redgram stalks + Glyricidiasp. with C:N ratio of 30:1 compost @ $50 \mathrm{~kg} \mathrm{~N}$ equivalent $\left(224.7 \mathrm{~kg} \mathrm{ha}^{-1}\right)($ Table 4$)$. This may be attributed to addition of more nitrogen to soil through organics and its slow release pattern throughout the growth period, which might have minimized nitrogen loss. These results are in line with Reddy and Reddy (1998) and Manna et al. (2005) reported that uptake of phosphorus is synergistic with uptake of nitrogen and higher uptake could be due to solubilization effect of organic acids produced by phosphorous solublizing bacteria and during decomposition of compost improved aeration and better root proliferation. Available nitrogen content of the soil was lower with the recommended NPK fertilizers $\left(T_{12}\right)$. This may be due to the higher concentration of ammonical nitrogen in the fertilizers which might have lost either through volatilization or through denitrification process. The significant build up of available nitrogen due to different compost and chemical fertilizers along with FYM application could be attributed to increased activity due to microbes which releases the nutrients to soil.
Maximum available phosphorus content in soil with the application of recommended FYM $\left(3 \mathrm{t} \mathrm{ha}^{-1}\right)$ and NP fertilizers $\left(50: 25 \mathrm{~kg} \mathrm{~N}, \mathrm{P}_{2} \mathrm{O}_{5} \mathrm{ha}^{-1}\right)$ application $(87.0 \mathrm{~kg}$ $\mathrm{ha}^{-1}$ ) followed by Cotton stalks +Redgram stalks + Glyricidiasp. with C:N ratio of 30:1 compost @ $50 \mathrm{~kg}$ $\mathrm{N}$ equivalent $\left(81.3 \mathrm{~kg} \mathrm{ha}^{-1}\right)$ (Table 3) may be attributed to more phosphorus added to soil. Similarly, Sharma and Saxena, 1985 reported that organic acids and carbon dioxide released during decomposition might have acted on native insoluble iron and aluminium phosphates resulting in release of insoluble phosphorus or might have chelated active $\mathrm{Fe}^{3+}$ and $\mathrm{Al}^{3+}$ reducing fixation or formation of insoluble iron and aluminium phosphates. The results of the present study also confirms the findings of Ravi Kumar (2009) and Katkar et al. (2012) that maximum build-up of soil $\mathrm{P}$ was observed under NPK + farmyard manure. This might be attributed to build up of $\mathrm{P}$ in soil by its addition every year and solubilization of native $\mathrm{P}$ in the soil through release of organic acids from farmyard manure.

Potassium content of soil increased with the application of recommended FYM with fertilizers or organics alone (Table 4) which may be due to addition of more potassium ( 27 to $83 \mathrm{ka} \mathrm{ha}^{-1}$ ) to the soil through composts alone or in combination with chemical fertilizers. Kihanda et al. (2007), Ravi Kumar (2009) and Katkar et al. (2012) also obtained similar results like that higher available K was by 18.6 per cent as compared to NPK treated plots. Continuous cropping without addition of $\mathrm{K}$ and imbalanced fertilization (N and NP) reduced the availability of $\mathrm{K}$ as compared to initial soil $\mathrm{K}$ status. Increase in available $\mathrm{K}$ might be due to the direct addition to the available $\mathrm{K}$ pool of the soil besides reduced $\mathrm{K}$ fixation and release of $\mathrm{K}$ due to the interaction of organic matter with clay. 


\section{Conclusion}

The results of the investigation showed that application of recommended FYM@ $3 \mathrm{t} \mathrm{ha}^{-1} 15$ days before sowing along with $50 \mathrm{~kg}$ of nitrogen and $25 \mathrm{~kg}$ of phosphorus $\mathrm{ha}^{-1}$ at the time of sowing recorded higher uptake $\left(227.3,75.7\right.$ and $141.7 \mathrm{~kg} \mathrm{ha}^{-1}$, respectively), soil bacteria $\left(45.4 \times 10^{7} \mathrm{cfu} \mathrm{g}^{-1}\right.$ of soil $)$, fungi $\left(39.7 \times 10^{4}\right.$ cfu g $\mathrm{g}^{-1}$ soil) and actinomycetes $\left(23.9 \times 10^{3} \mathrm{cfu} \mathrm{g}^{-1}\right.$ soil $)$ populations at harvest and soil fertility status (234.0, 87.0 and $519.7 \mathrm{~kg} \mathrm{~N} \mathrm{P}_{2} \mathrm{O}_{5} \mathrm{~K}_{2} \mathrm{O} \mathrm{ha}^{-1}$ ) followed by use of compost@3 t ha ${ }^{-1}$ prepared with Cotton stalks + Redgram stalks + Glyricidia green biomass with initial $\mathrm{C}: \mathrm{N}$ ratio of $30: 1$ of the mixed composting material. Currently, the energy crises associated with hike in prices fertilizers has made the use of chemical fertilizers not only costly but also scarce at peak times of demand. Hence, it is imperative to make use of organic sources to maintain healthy crop growth and to obtain sustainable yield and quality.

\section{REFERENCES}

Bellaki, M. A., Badanur, V. P. and Setty, R. A. (1997). Influence of long term use of organic and inorganic sources of nutrients on crop yield and nutrient uptake by irrigated paddy. Karnataka J. Agric. Sci., 10: 659-663.

Deshpande, H. H., Devasenapathy and Nagaraj, M. Naik. (2010). Microbial population dynamics as influenced by application of organic manures in rice field. GreenFarming, 1(4): 356-359.

Hundekar, S. T., Badnur, V. P. and Satyanarayana, T. (1997). Influence of crop residues in conjunction with fertilizers on soil fertility, nutrient uptake and yield of sorghum. Karnataka J. Agric. Sci., 10 (1): 25-31.

Jackson, M. L. (1967). Soil Chemical Analysis, Prentice Hall of India Pvt. Ltd., New Delhi, p. 498.

Katkar, R. N., Kharche, V. K., Sonune, B. A., Wanjari, R. H. and Muneshwar Singh. (2012). Long term effect of nutrient management on soil quality and sustainable productivity under sorghum-wheat crop sequence in vertisol of Akola, Maharastra. Agropedology, 22(2): 103-114.
Kihanda, F.M., Warren, G.P. and Micheni, A.N., Effect of manure application on crop yield and soil chemical properties in a long-term field trials in semi arid Kenya, 471-485.

Lalitha Kadir, G., Prabhakara Reddy., Rana Rao, G., Karuna Sagar, G. and Chandrika, V. (2015). Soil available nutrient status, nutrient uptake, bulb yield and shelf life of onion as influenced by use of organic manures and panchakavya. National. Acedemy. Agric. Sci., 33(2): 1625-1629.

Manna, M. C., Swarup, A., Wanjari, R. H., Ravankar, H. N., Mishra, B., Saha, M. N., Singh,Y. V., Sahi, D. K. and Sarap, P. A. (2005). Long term effect of fertilizer and manure application on soil organic carbon storage, soil quality and yield sustainability under sub-humid and semi-arid tropical India. Field Crop Res., 93: 264-280.

Panse, V.G. and Sukhatme, P.U. (1967). Statistical Methods for Agricultural Workers. ICAR, New Delhi.

Ramakrishna Parama, V.R. and Atheefa Munawery. (2012). Sustainable Soil Nutrient Management. J. Indian Institute of Sci., 92:1-16.

Ravi kumar, H. S. (2009). Comparative performance of integrated organic nutrient supply systems on growth and yield of groundnut (Arachishypogaea L.). M. Sc.(Agri.) Thesis, Univ. Agric. Sci., Bangalore.

Reddy, G.B. and Reddy, S.M. (1998). Effect of organic manures and nitrogen levels on soil available nutrient status in maize soybean cropping system. J. Indian Soc. Soil Sci.,46 (3): 474-476.

Rita B. Patil and Varde, P. A. (1998). Microbial population in rhizosphere as influenced by high input rates of fertilizer application to sorghum on a Vertisol. J. Indian Soc. Soil Sci., 46(2): 223-227.

Sharada (2013). Studies on nutrient management practices through organics in greengram - Rabi sorghum cropping system. M.Sc. (Agri.) Thesis, Univ. Agric. Sci., Raichur.

Sharma, J.P. and Saxena, S.N. (1985). Utilization of phosphorus by maize as influenced by various sources of organic matter and applied phosphorus. J. Indian Soc. Soil Sci.,33: 561-567.

Subbaiah, B. Y.and Asija, G. L. (1956). A rapid procedure for estimation of available nitrogen in soils. Curr. Sci., 25: $259-260$. 